\title{
БОЛГАРИЯ В КОНТЕКСТЕ «СЛАВЯНСКОЙ ПОЛИТИКИ» СССР В ГОДЫ ВТОРОЙ МИРОВОЙ ВОЙНЫ
}

\section{Т. В. Волокитина}

Волокітіна Т. В. Болгарія в контексті «слов'янської політики» СРСР у роки Другої світової війни. В статті розгядається «слов'янська політика» СРСР, іiї розроблення, цілі та практична реалізація в роки Другої світової війни. Особливу увагу приділено антифашистській, передусім анти- німецькій, спрямованості цієї політики як ключовому чиннику, що вплинув на повернення до слов'янської ідеї, а також тому місцю, котре відводилося Болгарії у планах радянського політичного керівництва.

Ключові слова: СРСР; Болгарія; «слов’янська політика»; Друга світова війна.

Волокитина Т. В. Болгария в контексте «славянской политики» СССР в годы Второй мировой войны. В статье рассматривается «славянская политика» СССР, ее разработка, цели и практическая реализация в годы Второй мировой войны. Особое внимание уделено антифашистской, прежде всего, антигерманской направленности этой политики как ключевому фактору, повлиявшему на возвращение к славянской идее, а также месту, отводимому Болгарии в планах советского политического руководства.

Ключевые слова: СССР; Болгария; «славянская политика»; Вторая мировая война.

Vokokitina T. V. Bulgaria in the Context of the "Slavic Policy" of the USSR during the World War II. The present article is devoted to the soviet "slavic policy", its formulation, targets and application during the World War II. The special attention is given to the key factor influenced the coming back to the slavic idea - anti-fascist and primarily anti-German focus and also to the place of Bulgaria in the plans of the soviet leadership.

Keywords: USSR; Bulgaria; "slavic policy"; World War II.

Исследования по истории внешней политики СССР и международных отношений накануне и в годы Второй мировой войны, публикации документов, предпринятые в последнее время как российскими, так и болгарскими учеными, убедительно раскрывают существенное значение балканских проблем. Признано, что в указанный период они быстро выдвинулись на авансцену мировой политики, а Болгария в силу своего исключительного геополитического положения оказалась в эпицентре событий.

Основные перипетии борьбы за Болгарию между Германией и Советским Союзом развернулись в плоскости определения сферы интересов СССР в Юго-Восточной Европе. К настоящему времени детально исследованы предложения Москвы о заключении гарантийного пакта с Софией с последующим размещением на болгарской территории советского воинского контингента, установлена и глубинная подоплека острого интереса советского руководства к Болгарии, сфокусированного в одном слове - Проливы. Их «закрытие» и связанное с этим установление советского контроля над морским побережьем Болгарии позволило бы, как считали в Москве, минимизировать потенциальную угрозу совместных действий Германии и Великобритании против СССР в Черноморском бассейне. Вплоть до нападения Германии на Советский Союз, указывает израильский историк Г. Городецкий, Сталин считал такой неблагоприятный для советской стороны вариант развития событий возможным ${ }^{1}$. Наконец, о многом говорит и готовность советской стороны примкнуть к Тройственному пакту, превратив тем самым последний в четверной союз Германии, Италии, Японии и СССР, при условии, что станет реальностью советско-болгарский договор.

Для привлечения Болгарии на свою сторону в Москве были готовы поддержать болгарские территориальные претензии к Греции и Турции (Западная Фракия, Дедеагач ${ }^{2}$ Драма и Кавала), обеспечить поставки в страну на условиях займа зерна, хлопка, а также и некоторых видов сырья и прочих материалов «в форме и размерах», которые могли быть уточнены после заключения договора. 
Несмотря на соблазнительные предложения, официальная София, как отмечает российская исследовательница Е. Л. Валева, в целом «придерживалась линии на сдержанное и дозированное улучшение отношений с СССР, избегая при этом тесного сближения на политической основе» ${ }^{3}$. До весны 1941 г. болгарское правительство отказывалось также и от вступления в Тройственный пакт, следуя традиционному с межвоенных лет нейтралитету ${ }^{4}$, но затем было вынуждено уступить давлению немцев. Как известно, Берлину на той стадии удалось по большому счету переиграть Москву в болгарском вопросе, успешно использовать в качестве дезинформации предложение о превращении Тройственного пакта в четверной союз, не лишая до поры до времени советское руководство иллюзорных надежд на возможность связать Болгарию с СССР гарантийным пактом в целях прорыва к Проливам. Очевидно при этом, что к тому времени Гитлер, как точно заметил российский историк В. К. Волков, «уже давно выбросил в корзину» соглашение 1939 г., в то время как Сталин продолжал придерживаться договоренности с Берлином ${ }^{5}$. Несомненно, это свидетельствовало о слабости и непоследовательности советской позиции, о попытке сохранить советско-германский «альянс врагов» (определение Л. Я. Гибианского), не совместимый с налаживанием одновременного противодействия СССР Германии и западным державам 6 . Это неизбежно загоняло советскую дипломатию в тупик.

События весны 1941 г. (капитуляция Югославии, наступление Германии на Грецию с болгарской территории, захват немцами Крита) существенно изменили политическую и военно-стратегическую обстановку в Юго-Восточной Европе и Восточном Средиземноморье. Но и в новых условиях действия советской дипломатии по-прежнему отличала крайняя непоследовательность. Несмотря на очевидное нарастание военной опасности, советское руководство вовсе не стремилось к денонсации пакта с Германией. Вместе с тем подписание 5 апреля 1941 г. советско-югославского договора о дружбе, вопреки ясно выраженному недовольству Берлина, немецкий союзник расценил как проявление солидарности СССР с англо-югославо-греческим фронтом против Германии. Реакция последовала незамедлительно, и уже 8 мая под нажимом Берлина была прекращена деятельность югославской дипломатической миссии в Москве. Показательно, что на аудиенции у В. М. Молотова 21 июня 1941 г. в качестве доказательства антигерманской направленности политики СССР посол Ф. Шуленбург, наряду с требованиями Москвы предоставить ей гарантии в Болгарии и базы в Проливах, назвал и советско-югославский договор ${ }^{7}$.

Нападение фашистской Германии на СССР, естественно, скорректировало задачи советской внешней политики. Постоянной и главной доминантой, безусловно, становилось укрепление отношений с союзниками по антигитлеровской коалиции, но внутри этой доминанты существовали и сменяли друг друга различные приоритеты. Так, помимо вопросов военной и экономической поддержки Советского Союза со стороны Запада, довольно быстро в сфере внимания партнеров оказались задачи достижения договоренностей о послевоенном мирном устройстве.

Инициаторами здесь выступили западные союзники. Однако некоторые особенности их «поведения» обусловили резкие перемены в советской позиции, причем на протяжении короткого времени. Еще в июле 1941 г. в беседе с послом Великобритании в Москве С. Криппсом Сталин счел тему послевоенного урегулирования неактуальной, что, в принципе, было в тех условиях понятным. Однако попытка лидеров Англии и США монополизировать обсуждение вопросов будущего миропорядка, выразившаяся в подготовке и принятии в августе 1941 г. Атлантической хартии ${ }^{8}$ без ведома союзников, в том числе и СССР, насторожила Москву, стала, по всей вероятности, дополнительным стимулом к разработке собственных проектов. Формулируя концепцию безопасности на послевоенную перспективу, советская сторона обратилась к идее региональных пактов о взаимопомощи (для Великобритании - с Бельгией и Голландией, для Советского Союза - с Финляндией и Румынией9). Нельзя не заметить, что советские намерения уходили корнями в 20 -е 30-е гг. XX в., к концепции гарантийных пактов и предложениям европейской дипломатии дополнить «Западное Локарно» ${ }^{10}$ «восточным», тем более, что идея «Восточного пакта» ${ }^{10}$ частично была реализована осенью 1939 г. заключением пактов о взаимопомощи с Эстонией, Литвой и Латвией. Важнейшей составляющей новой советской концепции была ее антигерманская направленность. 
Следует заметить, что на этом этапе обсуждался ряд весьма интересных и перспективных положений будущего миропорядка. Во время визита в Москву в декабре 1941 г. министра иностранных дел Великобритании А. Идена Сталин согласился с созданием в будущей реконструированной Европе, в интересах поддержания мира и порядка, «военного союза демократических государств», руководимого каким-либо центральным органом и располагавшего «международной военной силой». Не возражал он и против создания в Европе, в том числе и на Балканах, «тех или иных государственных федераций» ${ }^{11}$.

Советский лидер пошел еще дальше на Тегеранской конференции руководителей трех союзных держав, выдвинув идею создания «важных стратегических пунктов» в Европе и на Дальнем Востоке с целью недопущения новой агрессии со стороны Германии и Японии. Эту идею с жаром (по его собственным словам, «на сто процентов») поддержал Ф. Рузвельт, поскольку она отвечала размышлениям американского президента о «мировых полицейских». Из материалов конференции становится ясно, что Сталин имел в виду, прежде всего, переход под совместный контроль союзников немецких и японских военных баз ${ }^{12}$. Впоследствии предполагалось также обсудить возможность контроля и над теми базами, которые предстояло разместить в странах, настроенных традиционно дружественно к Объединенным Нациям ${ }^{13}$. К сожалению, данная важная инициатива советской стороны, свидетельствующая о ее готовности к поискам альтернативы жесткому делению мира на сферы влияния, не получила развития, а впоследствии, в условиях начинавшихся «заморозков» в отношениях между союзниками, окончательно сошла на нет.

Важную грань в разработке альтернативных подходов к вопросам послевоенного миропорядка составило и обращение советского руководства к так называемой славянской идее ${ }^{14}$. В исторической литературе давно подмечен конъюнктурный характер ее использования в советской внешней политике ${ }^{15}$. И здесь исследователи едины. Позиции разнятся лишь в вопросе хронологии - одни авторы полагают, что реанимация славянской идеи в нашей стране проходила постепенно на протяжении 1939-1941 гг., т.е. являла собой проиесс, другие одномоментно связывают возрождение славянской идеи с нападением Германии на Советский Союз ${ }^{16}$. Этот вопрос нуждается в дополнительном прояснении, но отдельные факты, например, создание в 1939 г. на историческом факультете МГУ кафедры истории южных и западных славян и сектора славяноведения в Институте истории АН СССР, свидетельствуют об определенных подвижках в представлениях властей, обративших внимание на славянскую составляющую в спектре научной и общественной жизни еще до начала Великой Отечественной войны ${ }^{17}$.

Парадокс ситуации заключался в том, что в Москве понимали, в каких трудных условиях происходит возвращение к славянской идее. Наряду с реально существовавшим, подчас на уровне подсознания, феноменом славянской взаимности, славянского «родства», имелись и зримо проявлялись объективные сложности в отношениях между славянскими государствами и народами, обретая порой формы острых межславянских конфликтов. Примеры того, что «славянский котел» бурлил, многочисленны. Достаточно назвать участие СССР вместе с Германией в разделе Польши; захват Польшей после Мюнхена части чехословацкой территории - Тешенской Силезии и некоторых областей на севере Словакии; оккупацию Болгарией Юго-Восточной Сербии, включая южную часть Косова, и аннексию Вардарской Македонии. Помимо межгосударственных конфликтов существовало противостояние и внутри многонациональных славянских государств. В Польше драматический характер обрела развернувшаяся еще в межвоенный период полонизация украинского, белорусского и русского населения; в Чехословакии напряженность отмечала отношения чехов, словаков и русинов (карпато-украинцев); в Словакии - словаков, украинцев, русинов; в Югославском королевстве резко усилились антисербские настроения в Хорватии, Словении, Боснии и Герцеговине, Македонии. Имевшая место шовинистическая пропаганда расовых теорий, в частности, отрицание славянской принадлежности отдельных народов и утверждения, например, о родстве хорватов с готами, болгар с гуннами ${ }^{18}$ подливали масла в огонь. Непростой была и религиозная обстановка, поскольку практически все славянские страны являлись поликонфессиональными, и отношения между вероисповеданиями в некоторых из них отличались напряженностью. Напомним, в частности, о попытках создания «польского православия», сопровождавшихся ревиндикацией - изъятием церковной собственности и возвращением православных храмов католическому костелу ${ }^{19}$. 
Или о подготовленном в аппарате НКВД еще до войны плане «решения» униатской проблемы на западно-украинских и западно-белорусских землях путем организации раскола «между сторонниками западного и восточного обрядов, используя существующие между ними противоречия», и дискредитации руководителей греко-католической церкви ${ }^{20}$. $($ Руководством к действию этот план стал после его одобрения Сталиным в марте 1945 г., на рубеже войны и мира).

С учетом вышесказанного нетрудно было прогнозировать сосуществование и в дальнейшем разнонаправленных тенденций - к сплочению славянских народов и к их разъединению, причем «центробежная» составляющая баланса между этими тенденциями была отнюдь не бесспорной.

Начало Великой Отечественной войны и особенно неудачи первого ее периода заставили советское руководство коренным образом пересмотреть старый идеолого-пропагандистский «багаж» во имя победы над врагом. Произошло, по оценке югославского коммуниста М. Джиласа, обращение Сталина «к исконным стремлениям и самобытности русского народа» ${ }^{21}$, неизбежно предполагавшее деидеологизацию советской политики. Во внешнеполитической сфере советское руководство отказалось, хотя и не сразу, от лозунгов классовой международной солидарности и приступило к поиску новых путей консолидации антифашистских, в первую очередь, антигерманских, сил. Одним из главных векторов этого процесса явились обращение к традициям борьбы славянских народов против немецкой политики «Дранг нах Остен», разоблачение гитлеровских планов установления мирового господства немецкой «высшей расы», физического уничтожения славян ${ }^{22}$. Ныне хорошо известно, что в соответствии с «Генеральным планом Ост» истреблению подлежали до 30 млн. русских, поляков, украинцев, белорусов, чехов и представителей других «неполноценных» народов, а свыше 50 млн. чел. предполагалось переселить в Западную Сибирь, на Северный Кавказ, в Южную Америку и Африку, освобождая «жизненное пространство» для населения Великой Германии. Советскими идеологами в качестве пропагандистского инструмента в мобилизационных целях на вооружение была взята и стала активно использоваться идея солидарности славянских народов с Россией.

Разнообразную работу в этом направлении возглавил и координировал созданный в Москве в октябре 1941 г. Всеславянский комитет, в состав которого вошли коммунисты и представители левых сил Польши, Чехословакии, Болгарии, Югославии. В активе Комитета - проведение в Москве трех всеславянских радиомитингов (август 1941, апрель 1942, май 1943) и митинга воинов-славян из сформированных на территории СССР соединений (февраль 1944) ${ }^{23}$, систематическое радиовещание на славянские страны с лета 1942 г., издание на славянских языках ежемесячного журнала «Славяне», активное сотрудничество со славянскими организациями Великобритании, США, Канады, Австралии, Аргентины и других стран. Пропагандистская деятельность Комитета, несомненно, стала одним из факторов усиления международного сопротивления фашизму ${ }^{24}$, но ее не следует преувеличивать и тем более абсолютизировать, учитывая сложную обстановку в славянском мире, в частности, значительные масштабы коллаборации. Эмоциональные заявления о единстве славянского мира в противостоянии нацизму в годы войны были, на наш взгляд, все же в большей мере пропагандистским клише, подменявшим желаемым действительное. Тем не менее, славянская идея очень скоро оказалась востребованной в практическо-политическом плане ${ }^{25}$. В лексиконе советского руководства появилось определение «славянская политика». Ее основу составляла идея пакта о взаимопомощи между славянскими народами, причем пакта пролонгированного - как на время войны с Германией, так и на послевоенный период ${ }^{26}$. Таким образом, концепция региональных пактов была усилена за счет включения в нее национально-исторической компоненты. Будущему региональному союзу в Восточной Европе предстояло, по крайней мере на первых порах, обрести в значительной мере «славянский» облик.

Важным направлением «славянской политики» становились действия в конфессиональной сфере. Далеко идущие размышления Сталина о формировании в лице Московской патриархии «ядра», способного впоследствии объединить вокруг себя поместные православные церкви, установить гегемонию Русской православной церкви в православном мире, сконцентрировались в лаконичной формуле «создать московский Вати- 
кан». Представляется, что параллель с всемирным центром католицизма выдавала также расчет на активное участие РПЦ во внешней политике под руководством и контролем государства. Иначе не могло и быть, учитывая традиционную ее приверженность цезаропапистской модели государственно-церковных отношений. Советское руководство получало, таким образом, в свои руки важный инструмент для расширения влияния, а впоследствии закрепления в мировом общественном мнении завоеванного в войне статуса СССР как сверхдержавы. Замысел создания «московского Ватикана» возник не вдруг и не на пустом месте. Он соблазнял религиозное сознание православного клира, причем, не только в Советском Союзе, напоминая о традиционных представлениях о «Руси - втором Иерусалиме» и «Москве - третьем Риме» (напомню, что идея тверского инока Фомы «Русь - второй Иерусалим» приписывала русскому православию официальное богословское определение универсальной Вселенской церкви, а творение старца псковского Елеазарова монастыря Филофея «Москва - третий Рим» первоначально обосновывало широкую миссионерскую деятельность Русской православной церкви среди нехристианских народов). Однако в новых условиях созвучные этим представлениям настроения приобретали иное качество: в религиозно-духовном плане они сопрягались с утверждением «вселенскости» русского православия. (Вот как сказал об этом глава Западноевропейской православной епархии митрополит Евлогий (Георгиевский): «Огромная непобедимая Россия, от Ледовитого океана до Индийского..., гроза пограничных сильных держав, покровительница малых, сестра родная всех славян... и Москва - кто знает! - быть может, всемирный центр православия.... $\left.{ }^{27}\right)$. Очевидно, что подобная трактовка не только не противоречила внешнеполитическим «мечтам» советского руководства, но и вполне логично соотносилась с ними.

Представляется, что внимание к славянской идее, экстраполированной на послевоенное время, усиливалось по мере все более зримого выявления противоречий в лагере союзников. При этом германский фактор продолжал оказывать серьезное воздействие на советское руководство, подозревавшее, что в будущем не исключено соглашение западных союзников с немцами. (Позднее, в марте 1945 г., во время пребывания в Москве чехословацкой делегации, Сталин обозначил эти подозрения в четкой формулировке о намерении союзников «спасти немцев и сговориться с ними... обойтись с ними помягче» ${ }^{28}$ ). С учетом этого происходила явная корректировка представлений Москвы о перспективах послевоенного урегулирования. С опасением теперь воспринимались проекты федерирования Европы, активно прорабатывавшиеся на Западе, поскольку с созданием наднациональных объединений в Москве ассоциировались возможности возрождения «санитарного кордона» на западных границах СССР.

К середине 1943 г. Москва окончательно определила свое в целом негативное отношение к идее федерирования, что, однако, не стало препятствием для тщательной аналитической работы, проводимой в НКИД СССР. Учитывая позиции союзников, в советском внешнеполитическом ведомстве тщательно просчитывали разнообразные варианты федераций, уточняли их возможный состав и параметры, прежде всего экономические. В Комиссии наркомата по подготовке мирных договоров и послевоенного устройства, руководимой М. М. Литвиновым, изучались такие объединения, как Адриатическая, Скандинавская, Дунайская монархическая, Польско-Чехословацкая и Центрально-Восточноевропейская федерации, Северный и Южный славянские союзы и пр. По меньшей мере, три варианта федераций предусматривали участие в них Болгарии: Дунайская (Австрия, Румыния, Болгария, Венгрия, Югославия), Балканская (Югославия, Румыния, Болгария, Греция) и Федерация стран Центральной и Юго-Восточной Европы (Австрия, Чехословакия, Польша, Венгрия, Румыния, Югославия, Болгария, Греция) ${ }^{29}$.

Для выяснения сущностных черт «славянской политики» весьма важны материалы, связанные с визитом в Москву в декабре 1943 г. президента Чехословакии Э. Бенеша, последовательного сторонника идеи славянского единства в целях противодействия Германии. Эту идею, считал он, «можно реализовать только в сотрудничестве с Советским Союзом на основе полного равноправия и независимости славянских народов». Однако чехословацкого руководителя, судя по документам, весьма беспокоила готовность Москвы следовать «славянской политике» в реальности, искренность советской стороны и даже такой конкретный вопрос: сможет ли грузин Сталин понять славянскую идею, 
как сами славяне? (В связи с этим заметим, что, будучи этническим грузином, Сталин называл себя «русским грузином»). Советская сторона поспешила успокоить Бенеша, подчеркнув, в частности, что «славянскую политику» СССР не следует трактовать как какой-то новый «панрусизм», как производное от старого русского империализма, что эта политика искренняя и являет собой центральную проблему всей внешнеполитической деятельности $\mathrm{CCCP}^{30}$.

Советско-чехословацкий договор, заключенный в декабре 1943 г., стал первым шагом в реализации идеи пакта о взаимопомощи славянских государств. Западными аналитиками он был расценен адекватно - как вероятная модель будущих взаимоотношений СССР с другими странами Центрально-Восточноевропейского региона ${ }^{31}$. Забегая вперед, напомним, что в апреле 1945 г. были подписаны аналогичные советско-югославский и советскопольский договоры. Они стали своего рода несущей конструкцией в будущем объединении государств Восточной Европы, призванном обезопасить западные границы СССР.

В августе 1944 г. свое представление о «славянской политике» изложил Сталин. В беседе с американским католическим священником польского происхождения Станиславом Орлеманьским он говорил о своей «мечте» - «возродить политику Грюнвальда на широкой основе» ${ }^{32}$. Советский лидер не случайно вспомнил о далеком времени, когда 15 июля 1410 г. около местечка Грюнвальд войска Польши и Великого княжества Литовского под руководством Владислава II Ягелло окружили и нанесли поражение немецкому Тевтонскому ордену, положив конец продвижению тевтонов на Восток. Представляется, что обращение Сталина к событиям XV в. подтверждает его замысел включить славянский союз в послевоенную систему безопасности в качестве важной составляющей.

Опубликованные к настоящему времени документы свидетельствуют, что в августе 1944 г. и на протяжении января-марта 1945 г. Сталин неоднократно, в беседах с польскими, болгарскими, югославскими и чехословацкими руководителями - Ст. Миколайчиком, Г. Димитровым, Й.-Б. Тито, Э. Бенешем, обосновывал важность создания «союза независимых славянских государств», тесно увязывая это с опасностью восстановления Германии, но решительно отмежевываясь от старого, «царского», славянофильства ${ }^{33}$. При этом он счел необходимым дать развернутую характеристику «нового славянофильства» и его цели - объединить славянские народы как равные для защиты совместными усилиями своего существования и будущего. Сталин охарактеризовал «старых славянофилов» как реакционеров, мечтавших собрать всех славян в едином государстве под эгидой России, осудил «царский великодержавный панславизм», причислил себя и своих соратников к «новым славянофилам-ленинцам, славянофилам-большевикам» ${ }^{34}$, для которых союз славянских народов становился своего рода верую.

Два момента представляется необходимым отметить в связи с этим. Во-первых, откровенно высказывавшиеся Сталиным опасения стремительного восстановления экономического и военного потенциала Германии. Впервые Сталин поднял этот вопрос в Тегеране в беседе с Ф. Рузвельтом 29 ноября 1943 г., заметив, что, «если Германию ничего не будет сдерживать», то она сможет восстановиться в течение 15-20 лет ${ }^{35}$. Позднее советский лидер не раз возвращался к этой теме. Показательно, что, в отличие, например, от югославов, отводивших немцам на восстановление 50 лет, Сталин подчеркивал, что «не нужно долго ждать восстановления немецкой силы». Более того, на протяжении весны-лета 1945 г. он неоднократно уменьшал эти сроки: называл 15, 15-12 и, наконец, 6 лет. Этого, подчеркивал Сталин, «хватит..., и Германия снова ...может угрожать новой войной» ${ }^{36}$. Во-вторых, несомненно, оборонительный характер будущего союза. По мысли Сталина, «постоянный союз... славянских народов раз-навсегда противопоставится немецкой агрессии и явится основой мира в Европе» ${ }^{37}$.

В современной исторической литературе можно встретить утверждение о нереальности германской угрозы в будущем, после разгрома фашизма ${ }^{38}$. Отсутствие при этом какихлибо комментариев способно породить подозрения в спекулятивных действиях советской стороны, использовавшей мифическую «германскую угрозу» в собственных геополитических целях. Однако намерение «сдержать Германию» демонстрировали в то время и западные союзники. Британское правительство, например, размышляя над созданием «системы региональной обороны в Западной Европе», допускало создание «каких-либо объединений» антигерманской направленности и на востоке континента ${ }^{39}$. Государствен- 
ный секретарь США Д. Бирнс указывал на общую цель СССР и США - «держать Германию разоруженной в течение 20-25 лет», для чего американцы зондировали возможность заключения договора с советской стороной ${ }^{40}$. Иными словами, союзники по антигитлеровской коалиции были далеки от того, чтобы не считаться в будущем с германским фактором, и это обстоятельство следует учитывать.

Намерение обозначить контуры будущего союза восточноевропейских стран как объединения славян вызвало к жизни тенденцию безосновательного расширения «славянской семьи», включив в нее народы с абсолютно иным этническим происхождением. Причем, тенденция эта формировалась совместными усилиями сторон. Так, в январе 1945 г. на встрече с югославской делегацией Сталин бросил реплику, что «албанцы тоже славяне по происхождению» ${ }^{41}$, а в апреле 1945 г. один из лидеров крестьянской Национал-царанистской партии Румынии Н. Лупу изложил политсоветнику Союзной контрольной комиссии в Румынии А. П. Павлову свою «теорию» происхождения румын, как «народа, родственного славянам $\rangle^{42}$.

Вместе с тем четкого представления об организационной форме будущего союза не существовало. Скорее всего, он мыслился как сравнительно гибкая система двусторонних пактов: допускалась их трансформация в сторону расширения (например, советско-чехословацкий договор 1943 г. с согласия сторон мог быть превращен в перспективе в трипартитный за счет подключения к нему Польши).

Отношение к конкретным славянским странам, естественно, претерпевало, изменения, обусловленные политическими реалиями в них и ходом событий в международном масштабе. Не стала исключением и Болгария. Если в декабре 1941 г., согласовывая с А. Иденом «схему реорганизации европейских границ после войны», Сталин предлагал «наказать Болгарию за ее поведение во время войны», отторгнув у нее район Бургаса («По мнению тов. Сталина, для Болгарии совершенно достаточно иметь один морской порт в виде Варны», - указывалось в записи беседы $\left.{ }^{43}\right)$, то впоследствии, по мере приближения окончания войны, позиция Москвы мало-помалу меняется. На встрече с Черчиллем в Москве в октябре 1944 г. в ответ на резкие высказывания британского премьера в адрес болгар Сталин ограничился лаконичной репликой: «Болгарию, конечно, нужно наказать» ${ }^{44}$. А в Потсдаме летом 1945 г. советский лидер, говоря о «грехах» сателлитов по отношению к России, наказание славянского сателлита свел к уплате Болгарией репараций и демобилизации регулярной армии по окончании войны. Мотивировкой при этом явилось отсутствие болгарских воинских частей на Восточном фронте и их участие в войне на стороне союзников в соответствии с Соглашением о перемирии ${ }^{45}$.

Вместе с тем советская сторона отклонила предложение Славянского комитета Болгарии созвать в Софии в марте 1945 г. Славянский конгресс, приурочив его ко дню национального освобождения страны в результате русско-турецкой войны 1877-1878 гг. Всеславянский комитет заявил: как бывшая союзница Германии, Болгария еще должна заслужить право стать хозяйкой конгресса ${ }^{46}$. Вместе с тем, явно желая поддержать болгар, Москва дала согласие на проведение в Софии Славянского собора, понизив, таким образом, статус предстоящего форума. Конгресс, как известно, состоялся годом позже в Белграде. Документы Союзной контрольной комиссии в Болгарии показывают, что советская сторона придавала софийскому мероприятию большое значение как «реабилитации болгарского народа в глазах всех славян и в глазах других народов мира» ${ }^{47}$.

Как и следовало ожидать, материалы Славянского собора четко отразили его направленность против возможной германской угрозы в будущем. «Иллюзией является мысль, что германская опасность исчезнет сразу же с разгромом гитлеровской Германии, - подчеркнул в своем выступлении В. Червенков. - Самым лучшим щитом против германской опасности для славянских народов является всестороннее укрепление созданного в этой войне боевого союза славянских народов» ${ }^{48}$.

Примечательно, что в выступлениях болгарских участников настойчиво акцентировалась мысль о «противоестественности» союза болгар с Германией и «оскорбительном положении» страны в связи с этим, о пагубной роли болгарских монархов - носителей «органической вражды к славянским народам и, особенно, к великому русскому народу», о настроениях славянской солидарности среди болгар, которые привели их после освобождения «в объятия братьев-славян» и пр. ${ }^{49}$. «Мы рождаемся снова, заявил экзарх 
Болгарский Стефан, подобно блудному сыну возвращаемся к самим себе...». Указав на славянство как «первенствующую расу», владыка предложил утвердить русский язык в качестве «духовного мощного рычага», сделать его «обязательным для всех славян» ${ }^{50}$.

Эйфория, охватившая участников Славянского собора, нашла отражение в эмоциональных прогнозах на будущее: [После победы], говорила Ц. Драгойчева, «перед славянскими народами откроются широкие горизонты для подъема и творческой работы. Кипящие энергией славянские народы развернут свои силы для творчества и взаимной помощи так, как они это делают в настоящее время, ведя борьбу за полное уничтожение фашистского агрессора. Они не только восстановят разоренное гитлеровскими варварами хозяйство, но и станут творцами радостной и счастливой жизни, вольют новые свежие силы в общечеловеческую культуру и цивилизацию» ${ }^{51}$.

Не был обойден вниманием и принципиальный вопрос о равноправии всех членов славянской семьи, не совместимом с проявлениями «старого панславизма» ${ }^{52}$. В обобщенном виде позицию болгарского руководства по «славянской политике» изложил видный общественный деятель, ученый-философ, один из регентов при малолетнем царе Симеоне коммунист Т. Павлов в интервью белградским газетам «Борба» и «Политика». «Идея братского сотрудничества между славянскими народами, говорил Павлов, является, во-первых, идеей обеспечения и развития их различных национальных государств и культур; во-вторых, средством для общей защиты от будущих нападений тевтонизма; в-третьих, средством для преодоления шовинизма и национальной ограниченности. Кроме того, она является естественным путем или ступенью к переходу от узкой национальной государственности и культуры к более широкой демократической космополитической государственности и культуре (курсив мой - T. В.). Таким образом, идея славянской солидарности, как она конкретно теперь обрисовывается, и при наличии СССР, с одной стороны, и тевтонской империалистической опасности, с другой, не имеет ничего общего с прошлым царским панславизмом; напротив, она является, безусловно, прогрессивным фактом и фактором европейского и мирового значения. При этом никогда не надо забывать, что признание особенностей культурно-национального характера славянских народов ни в коем случае не означает, что они стали расистами, шовинистами и империалистами» ${ }^{53}$.

Возвращаясь к советским разработкам, связанным с послевоенным урегулированием, следует отметить, что перспективы Болгарии как малой балканской страны рассматривались в одной связке с другими странами региона. О том, в каком направлении размышляло советское руководство, свидетельствуют документы вышеупомянутой комиссии Литвинова.

В Записке по вопросам будущего мира и послевоенного устройства, датированной 11 января 1944 г. (в секретариате А. Я. Вышинского она была зарегистрирована под названием «Мысли о желательных основах послевоенного мира»), ее автор - дипломат И. М. Майский сформулировал возможные варианты нового миропорядка, исходя из двух «сценариев»: при наличии и отсутствии «пролетарских революций» в Европе. В зависимости от этого ожидалось сохранение партнерских отношений с Западными державами или, наоборот, их обострение, поскольку противоречие капитализм-социализм станет, полагал Майский, определяющим фактором международной обстановки. Общие стратегические установки конкретизировались при изложении вопросов о послевоенных границах и положении отдельных регионов и стран Европы. Применительно к Балканам Майский прогнозировал создание системы двусторонних пактов СССР с Румынией, Югославией и Болгарией. Характерно, что, подчеркивая чрезвычайную заинтересованность Англии в греческих делах, советский дипломат не ставил прямо вопрос об особом интересе СССР в других районах Балканского полуострова. Предпринятая им в записке «расшифровка» значения заключения пактов ясно свидетельствовала о претензиях Москвы на доминирование в конкретных странах. Пакты означали предоставление СССР на территории этих стран необходимого количества военных, воздушных и морских баз, создание стратегически и экономически важной системы сообщения. В результате Румынии предстояло стать «важным фактором нашей (СССР. - T. B.) обороны на юго-востоке» европейского континента, пакты с Румынией и Болгарией рассматривались, как лучший способ ослабить позиции «часового» на Проливах - Турции. Для этого, подчеркивал Майский, «должны быть 
использованы все возможности». Стратегическими соображениями обуславливалось и решение территориальных проблем. Так, подчеркивая необходимость возврата Болгарией земель, аннексированных у Югославии и Греции, Майский делал весьма характерную оговорку о желательном удержании Болгарией Дедеагача, что «могло бы представлять интерес для СССР в случае заключения советско-болгарского пакта взаимопомощи». «В соответствии с интересами СССР» предлагалось разрешить вопрос и о границе между Болгарией и Румынией в Южной Добрудже. Вопрос о получении репараций с балканских союзников Германии Майский формулировал в общем виде: «Румыния и Болгария должны быть привлечены к платежам репараций», однако Болгария - «в меньшей степени». Четко зафиксирована в Записке негативная позиция относительно создания упоминавшихся выше федераций малых стран Европы - Дунайской, Балканской, Центрально-Европейской, Скандинавской и т.п., чье появление на карте, подчеркивал Майский, не отвечало бы интересам СССР, по крайней мере, непосредственно после войны ${ }^{54}$.

Характерно, что в документах Комиссии в качестве основополагающего доминировал геополитический подход, основанный на разделении мира на сферы влияния или, иначе, на «зоны ответственности». В апреле 1944 г. в Записке о международной организации безопасности Литвинов указывал на тактическую нецелесообразность каких-либо инициатив советского правительства по выдвижению предложений о делении мира на сферы влияния, хотя и признавал, что «при конкретном уточнении и распределении между великими державами обязательств по сохранению мира вопроса о зонах не избежать» ${ }^{55}$. Состоявшееся в Москве в октябре 1944 г. «процентное соглашение» между Сталиным и Черчиллем полностью подтвердило этот прогноз.

Материалы Комиссии Литвинова свидетельствуют, что в ее недрах и позднее продолжалась тщательная проработка возможных вариантов оформления послевоенного миропорядка. В датированном 15 ноября 1944 г. одном из важных документов «О перспективах и возможной базе советско-британского сотрудничества», вышедшем из-под пера руководителя Комиссии, к «максимальной сфере интересов Советского Союза» были отнесены Финляндия, Швеция, Польша, Венгрия, Чехословакия, славянские страны Балканского полуострова и Турция. Ключевой для СССР вопрос о Проливах Литвинов рассматривал через призму возможной интернационализации режима их использования, причем четко обозначив, какая интернационализация была бы приемлема для советской стороны. Признавая перспективу «энергичного» противостояния Запада (в первую очередь, Англии), советский дипломат считал, тем не менее, единственно возможным вариантом передачу контроля над Проливами исключительно черноморским державам «при наличии условий, обеспечивающих дружественные отношения к нам со стороны Румынии и Болгарии» ${ }^{56}$. Под такими «условиями» Москва, как свидетельствуют официальные заявления советских руководителей, понимала создание дружественных СССР режимов, подчеркивая «незаинтересованность» во введении социалистических порядков ${ }^{57}$. На обеде в честь Э. Бенеша 28 марта 1945 г. Сталин заметил: «Мы могли бы в Болгарии установить советский строй, там этого хотели. Но мы не пошли на это. В дружественных нам славянских странах мы хотим иметь подлинно демократические правительства» ${ }^{58}$. Конкретные материалы указывают, что на том этапе Москва принимала как адекватную сложившимся в Восточной Европе реалиям коалиционную систему осуществления власти, откладывая «на потом» социалистическую перспективу.

Приведенные нами выше документы Комиссии Литвинова имели рабочий характер, отражали, так сказать, «информацию для размышления». Однако важность их для анализа процесса выработки внешнеполитического курса Советского Союза очевидна. С точки зрения заявленной темы весьма показательно, что ни в одном из них мы не найдем замыслов создания «славянского союза» в формате некоего государственного объединения.

Означал ли этот факт понимание советскими разработчиками несвоевременности, а, может быть, и утопичности подобного замысла? Вполне возможно. В беседе с Черчиллем и Иденом в октябре 1944 г. Сталин заметил, что после войны главным желанием народов будет пожить «полной национальной жизнью без помех» ${ }^{59}$. Иными словами, невозможно, полагал советский лидер, думать всерьез о каких-либо масштабных объединениях. Но, похоже, Сталин подразумевал не только планы Запада по федерированию Европы. В марте 1945 г. на встрече с чехословацкой делегацией Сталин объявил идею объединения славян 
«под русским царем» «вредной и невыполнимой», пояснив: «Славянские народы имеют различные общественно-бытовые и этнографические уклады, имеют разный культурный уровень и различное общественно-политическое устройство. Географическое положение славянских народов также мешает объединению. Мы... стоим не за объединение, а за союз славянских народов. ...Этот союз необходим нам для защиты славянства» (курсив мой T. B. $)^{60}$. С учетом сказанного логично предположить, что приведенные выше рассуждения Т. Павлова о некой (славянской) «космополитической государственности и культуре» вряд ли могли импонировать Сталину.

Представляется, что, будучи политиком-реалистом, советский лидер предвидел трудности практического воплощения каких-либо государственных форм «славянского союза». Не мог он не учитывать и неизбежную негативную реакцию Запада. Понимание Москвой сложности вопроса подтверждают документы, связанные с обсуждением советскими руководителями разработанного Заграничным руководством КПЧ весной 1945 г. проекта программы будущего чехословацкого правительства. Изучив проект, советская сторона констатировала отсутствие в нем «чувства меры в вопросе об отношении к Советскому Союзу и к единству славянских народов» (предлагала в связи с этим «подчеркнуть также укрепление дружественных отношений Чехословакии с Англией, США, Францией и др[угими] объединенными нациями»), рекомендовала пересмотреть «скользкие формулировки о славянской линии внешней политики, среднеевропейском и восточноевропейском объединении славянских народов и т.n.» (курсив мой - T. В. $)^{61}$.

Ближайшее будущее, в частности, попытки создания южнославянской федерации/ конфедерации в составе Болгарии и Югославии и заключения таможенной унии подтвердили сложность решения подобных задач. При рассмотрении конкретных форм объединения двух балканских стран верх взяли прагматизм лидеров, внешнеполитические обстоятельства и, как допускает российская исследовательница Н. В. Васильева, «национальный эгоизм» ${ }^{62}$.

В последнее время много говорится о «славянском проекте» Сталина, предполагавшем создание к 1953-1954 гг. Славянского союзного конфедеративного государства (ССКГ) в двух возможных вариантах (СССР, Польша, Чехословакия, Болгария, Югославия или упомянутые государства плюс Украина и Белоруссия. Столицей ССКГ могли быть соответственно Белград, Минск, София или Варшава) ${ }^{63}$. Авторы, не приводя прямых документальных подтверждений наличия такого стратегического замысла, усматривают начало его реализации в подписании двусторонних договоров СССР со славянскими странами, во вступлении Украины и Белоруссии в ООН в 1945 г. Между тем, даже значительно более узкий вариант «Славянского союза» в составе Польши, Чехословакии и Украины, о котором от своего имени говорил А. Е. Корнейчук (известный драматург и замнаркома иностранных дел СССР) в беседе с Э. Бенешем в начале декабря 1943 г. на английской военной базе под Багдадом, по пути в Москву, вызвал неприятие в советских «верхах» и положил конец дипломатической карьере Корнейчука ${ }^{64}$.

Уже на рубеже войны и мира становилось ясно: «славянская политика» в Восточной Европе имеет ограниченный ареал применения уже потому, что в советскую сферу влияния войдут не только славянские страны. Предстояло искать и находить иные формы «сцепления» ее компонентов на основе не этнических, а геополитических, а затем и идеологических принципов. Возникший осенью 1947 г. «социалистический лагерь» не был государственным объединением идеологически однотипных стран, а трудности, возникшие уже на начальном этапе реализации болгаро-югославского проекта федерации, показали иллюзорность расчетов на якобы «особые отношения» между славянскими странами, основанные на солидарности и «уникальной» славянской ментальности.

Однако советские идеологи оставили славянскую идею на вооружении и по традиции время от времени эксплуатировали ее в конкретных политических и социальных целях. Так, на рубеже 1940-х - 1950-х гг. славянская идея использовалась, прежде всего, как пропагандистский инструмент, представляя СССР «старшим братом» и защитником других славянских народов. В наши дни обращение тех или иных политических и общественных сил к общим славянским «корням», озвучивание замыслов панэтнической реинтеграции некоторых славянских народов и государств ${ }^{65}$ указывают на то, что, вопреки историческому опыту, старая традиция жива и находит своих протагонистов. 
${ }^{1}$ См., например: выступление Г. Городецкого в дискуссии на международной научной конференции «Болгария и Россия в ХХ веке» (София, Институт истории БАН, 1995 г.) // България и Русия през XX век. Българо-руски научни дискусии. София, 2000. С. 221.

${ }^{2}$ Дедеагач - турецкое название города-порта Александруполиса в северо-восточной части Греции, во Фракии.

${ }^{3}$ Валева Е. Л. «Болгарская карта» в геополитической игре Москвы и Берлина (1939-1941 гг.) // България и Русия между признателността и прагматизма. Доклади. София, 2008. С. 391.

${ }^{4}$ Подробнее см.: Николов Р. Присъединяването на България към Тристранния пакт: военностратегически аспекти на политическия ангажимент // 100 години независима България: стълбовете на държавността. Сборник доклади и научни съобщения, изнесени на международна научна конференция в София, 14-15 октомври 2008 г. София, 2009. С. 136-144.

${ }^{5}$ СССР, Восточная Европа и Вторая мировая война. 1939-1941. Дискуссии, комментарии, размышления. М., 2007. С. 295.

${ }^{6}$ Там же. С. 293.

${ }^{7}$ СССР - Германия. 1939-1941. Документы и материалы о советско-германских отношениях с сентября 1939 по июль 1941 г. Т. 2. Вильнюс, 1989. С. 169.

8 Указанный документ фиксировал следующие принципы послевоенного устройства: непризнание территориальных изменений, осуществляемых вопреки желаниям заинтересованных народов; права народов самостоятельно избирать форму правления; восстановление суверенитета стран, лишенных его насильственным путем; разоружение государств - потенциальных агрессоров; уничтожение «нацистской тирании»; свобода мореплавания; равенство стран в торговле и доступе к источникам сырья.

${ }^{9}$ Подробнее об этом см.: Наринский М. М., Филитов А. М. Советская внешняя политика в период Второй мировой войны. Курс лекций по истории международных отношений (1939-1945 гг.). М., 1999. С. 74-75.

10 «Западное Локарно», или западноевропейский гарантийный пакт - договоры, подготовленные на конференции в Локарно в 1925 г. министрами иностранных дел Бельгии, Великобритании, Германии, Италии, Франции, Польши и Чехословакии. Основной документ - так называемый Рейнский гарантийный пакт - декларировал территориальный status quo, оформленный Версальским мирным договором 1919 г.: неприкосновенность германо-бельгийской и германо-французской границ, демилитаризация Рейнской области. Хотя франко-польский и франко-чехословацкий договоры, парафированные в Локарно, предполагали оказание помощи Польше и Чехословакии в случае нападения на них Германии, государства, подписавшие Рейнский пакт, не гарантировали восточные границы Германии. «Восточный пакт» - проект договора о взаимопомощи между СССР, Чехословакией, Польшей, Финляндией, Латвией, Эстонией и Литвой против возможной агрессии Германии. Замысел пакта принадлежал министру иностранных дел Франции Л. Барту и как документ был оформлен в начале 1934 г.

${ }^{11}$ Первая беседа с А. Иденом 16 декабря [1941 г.] в 19 часов 00 минут // Ржешевский О. А. Война и дипломатия. Документы, комментарии (1941-1942). М., 1994. Док. № 4. С. 18, 20.

12 Советский Союз на международных конференциях периода Великой Отечественной войны 1941-1945 гг. Том II. Тегеранская конференция руководителей трех союзных держав - СССР, США и Великобритании (28 ноября - 1 декабря 1943 г.). Сборник документов. М., 1978. Док. № 56. С. 117.

13 Там же. Док. № 60. С. 144-145.

${ }^{14}$ В русской общественной мысли, как и в национальном сознании, славянская идея подразумевала осознание духовно-культурной общности славянских народов и «особых» отношений России со славянским миром. Существуют разные уточняющие дефиниции «славянской идеи» - например, «славянское единство», «славянская взаимность», «славянская солидарность», «славянское движение». Славянская идея уходит корнями в далекое прошлое. Во второй половине XVII в. об объединении славян в одно государство под эгидой России говорил хорват Юрий Крижанич, а в первой половине XIX в. идею славянской взаимности обосновывали словаки Людовит Штур, Ян Коллар, Павел Шафарик.

${ }^{15}$ Марьина В. В. Славянская идея в годы Второй мировой войны (К вопросу о политической функции) // Славянский вопрос: вехи истории. М., 1997. С. 169-181.

${ }^{16}$ Славянские народы и Вторая мировая война (Материалы «круглого стола» 25 мая 1995 г. в Институте славяноведения и балканистики РАН) // Славяноведение. 1996. № 3. С. 4, 9-10 (выступления В. В. Марьиной и Н. Д. Смирновой).

${ }^{17}$ Подробнее см.: Досталь М. Ю. Сектор славяноведения Института истории АН СССР // Славянский альманах. 2002. М., 2003.

18 Petranović B. Istorije Jugoslavije. 1918-1978. Beograd, 1981. S. 139; Протоболгары - между историческими фактами и мифами. URL: www.portalostranah.ru/view.php?id=13 (дата обращения: 20.09.2017).

${ }^{19}$ Волокитина Т. В., Мурашко Г. П., Носкова А. Ф. Москва и Восточная Европа. Власть и церковь в период общественных трансформаций 40-х - 50-х годов XX века. М., 2008. С. 281-288. 
${ }^{20}$ Там же. С. 379.

${ }^{21}$ Джилас М. Беседы со Сталиным // Джилас М. Лицо тоталитаризма. М., 1992. С. 41.

22 Подробнее об антиславизме Гитлера и немцев см., например: Борейша Е. О понятии «антиславизма» у Адольфа Гитлера // Славянские народы: общность истории и культуры. К 70-летию члена-корреспондента Российской академии наук В. К. Волкова. М., 2000. С. 369-380.

${ }^{23}$ Подробнее о радиомитингах и участии в них болгарских представителей см.: Кикешев Н. И. Славянская идеология. М., 2014. С. 436-441, 444-450, 455-467.

${ }^{24}$ Васильева Н. В. СССР и «славянская идея» в балканском измерении: традиции и политические реалии (По опыту Второй мировой войны) // България и Русия: между признателността и прагматизма. Доклади. София, 2008. С. 489-491.

${ }^{25}$ Марьина В. В. Славянская идея в годы Второй мировой войны (К вопросу о политической функции) // Славянский вопрос: вехи истории. М., 1997. С. 176.

${ }^{26}$ Архив внешней политики РФ (далее - АВП РФ). Ф. 06. Оп. 4. П. 25. Д. 276. Л. $42-43$.

${ }^{27}$ Цит. по: Шкаровский М. В. Русская православная церковь при Сталине и Хрущеве (Государственно-церковные отношения в СССР в 1939-1964 годах). М., 1999. С. 291.

${ }^{28}$ Сталин И. В. Сочинения. Т. 18. Тверь, 2006. С. 361; Робертс Дж. Сталинские войны. От мировой войны до холодной. 1939-1953. URL: http://samlib.ru/w/worobhew_anatolij/stalin1-1.shtml (дата обращения: 20.09.2017).

${ }^{29}$ АВП РФ. Ф. 0512. Оп. 4. П. 12. Д. 20. Л. 1-17; Волокитина Т. Перспективы развития Болгарии после Второй мировой войны. Взгляд из Москвы (Новые документы российских архивов) // България и Русия през XX век. Българо-руски научни дискусии. София, 2000. С. 240.

${ }^{30}$ Fierlinger Z. Veslužbách CSR. Praha, 1947. S. 184-185; Марьина В. В. Визит Эдварда Бенеша в Москву: славянский вопрос (декабрь 1943 г.) // Славянский мир в третьем тысячелетии. Образ России в славянских странах. М., 2012. С. 109-112.

${ }_{31}$ АВП РФ. Ф. 06. ОП. 6. П. 14. Д. 143. Л. 28, 30.

32 Восточная Европа в документах российских архивов. 1944-1953: в двух томах / Отв. ред. Г. П. Мурашко. Т. І. 1944-1948. М., 1997. Док. № 3. С. 39.

33 Советский фактор в Восточной Европе. 1944-1953. Документы: в двух томах / Отв. ред. Т. В. Волокитина. Т. І. 1944-1948. М., 1999. Док. № 11. С. 86; Георги Димитров. Дневник (9 март 1933 г. - 6 февруари 1949 г.). София, 1997. С. 464: Djilas M. Wartime. New York, 1977. P. 437-438; Сталин И. В. Сочинения. Т. 18. Тверь, 2006. С. 359-361; Archivum Act Nowych (Warszawa). 295/VII244. S. 40-41.

${ }^{34}$ Сталин И. В. Сочинения. Т. 18. Тверь, 2006. С. 360.

35 Советский Союз на международных конференциях периода Великой Отечественной войны 1941-1945 гг. Том II. Тегеранская конференция руководителей трех союзных держав - СССР, США и Великобритании (28 ноября - 1 декабря 1943 г.). Сборник документов. М., 1978. Док. № 56. С. 117.

${ }^{36}$ Archivum Act Nowych (Warszawa). 295/VII-244. S. 40-41.

37 Российский государственный архив социально-политической истории (далее - РГАСПИ). Ф. 17. Оп. 128. Д. 733. Л. 70.

${ }^{38}$ См., например: Фатеев А. В. Образ врага в советской пропаганде. 1945-1954. М., 1999. С. 31.

39 Советско-английские отношения во время Великой Отечественной войны. 1941-1945. Т. 2. 1944-1945. M., 1983. C. 238-241.

${ }^{40}$ АВП РФ. Ф. 06. Оп. 7. П. 43. Д. 678. Л. 71-72.

41 Восточная Европа в документах российских архивов.1944-1953: в двух томах / Отв. ред. Г. П. Мурашко. Т. I. 1944-1948. М., 1997. Док. № 37. С. 132.

42 Там же. Док. № 66. С. 207.

${ }^{43}$ Первая беседа с А. Иденом 16 декабря [1941 г.] в 19 часов 00 минут // Ржешевский О. А. Война и дипломатия. Документы, комментарии (1941-1942). М., 1994. Док. № 4. С. 16.

${ }^{44}$ РГАСПИ. Ф. 558. ОП. 11. Д. 283. Л. 9.

45 Там же. Д. 236. Л. 11.

46 Досталь М. Ю. Белградский славянский конгресс победителей фашизма (1946) // Славянское движение XIX-XX веков: съезды, конгрессы, совещания, манифесты, обращения. М., 1998. С. 228.

${ }^{47}$ АВП РФ. Ф. 074. ОП. 34. П. 123. Д. 44. Л. 46.

48 Там же. Л. 62.

49 Там же. Л. 52, 57.

50 Там же. Л. 65, 66.

51 Там же. Л. 63.

52 Там же. Л. 60, 62, 77.

${ }^{53}$ Там же. Оп. 34б. П. 158а. Д. 4. Л. 45-46.

54 Советский фактор в Восточной Европе. 1944-1953. Документы: в двух томах / Отв. ред. Т. В. Волокитина. Т. І. 1944-1948. М., 1999. Док. № 1. С. 24, 29, 31, 32, 33, 41, 46.

${ }_{55}$ АВП РФ. Ф. 06. Оп. 6. П. 14. Д. 144. Л. 28.

56 Там же. Д. 143. Л. 52. 
${ }^{57}$ Волокитина Т. В., Мурашко Г. П., Носкова А. Ф., Покивайлова Т. А. Москва и Восточная Европа. Становление политических режимов советского типа. 1949-1953. Очерки истории. М., 2002. С. 32; Восточная Европа в документах российских архивов. 1944-1953: в двух томах / Отв. ред. Г. П. Мурашко. Т. І. 1944-1948. М., 1997. Док. № 3. С. 38.

${ }_{58}$ Сталин И. В. Сочинения. Т. 18. Тверь, 2006. С. 361.

${ }^{59}$ Цит. по: Васильцов С. Послевоенное устройство: новые сталинские подходы к внутренней и внешней политике. URL: http://rusmir.in.ua/ist/569-poslevoennoe-ustrojstvo-novye-stalinskie-podhody. html (дата обращения: 20.09.2017).

${ }^{60}$ Сталин И. В. Сочинения. Т. 18. Тверь, 2006. С. 361.

${ }^{61}$ Советский фактор в Восточной Европе. 1944-1953. Документы: в двух томах / Отв. ред. Т. В. Волокитина. Т. І. 1944-1948. М., 1999. Док. № 47. С. 176.

${ }^{62}$ Васильева Н. В. СССР и «славянская идея» в балканском измерении: традиции и политические реалии (По опыту Второй мировой войны) // България и Русия: между признателността и прагматизма. Доклади. София, 2008. С. 494.

${ }^{63}$ См., например: Балиев А. Славянский проект Сталина. URL: https://topwar.ru/19292-slavyanskiy-proekt-stalina.html (дата обращения: 20.09.2017); Волков Э. Славянский проект Сталина. URL: http://www.livinternet.ru/users/2503040/post174542949 (дата обращения: 20.09.2017); Дутов А. Проект Сталина - славянское союзное конфедеративное государство. URL: https://ok.ru.rodnayaveraveda/ topic/64878563554655 (дата обращения: 20.09.2017). - Все указанные публикации идентичны; Кикешев Н. И. Славянская идеология. М., 2014. С. 577-578.

${ }^{64}$ Марьина В. В. Визит Эдварда Бенеша в Москву: славянский вопрос (декабрь 1943 г.) // Славянский мир в третьем тысячелетии. Образ России в славянских странах. М., 2012. С. $112-113$.

${ }^{65}$ Романенко C. Национальное самоопределение и «славянская идея» // Право народов на самоопределение: идея и воплощение / Сост. А. Г. Осипов. М., 1997. URL: www.adhdportal.com/ book_2680_chapter_16_S.ROMANENKO._Nationalnoesamoopredelenie_i_slavjanskaja_ideja.html (дата обращения: 20.09.2017). 